\author{
اثر تزريق داخل يوستة هستة اكومبنسى اسيد آسكوربيك بر ياد تيرى و حافظة فضايى موشهاى

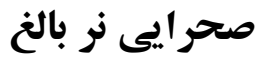

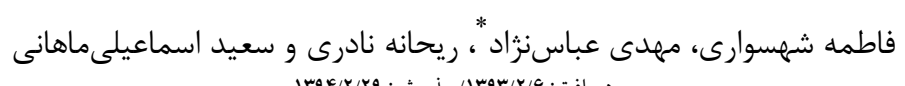 \\ دريافت: \\ كروه زيست شناسى، دانشكدة علوم، دانشكاه شهيد باهنر كرمان، كرمان \\ mabbas@mail.uk.ac.ir :مسئول مكاتبات دم: \\ جكيده. اسيد آسكوربيكك بهمنزلة يكك ويتامين و تعديل كنندهُ عصبى در بيشتر نواحى مغز بستانداران ازجمله بوستهُ هستهُ اكومبنس يافت مىشود. در تحقيق حاضر به

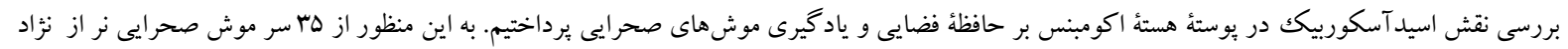

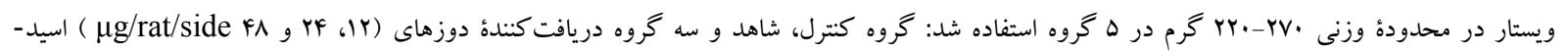

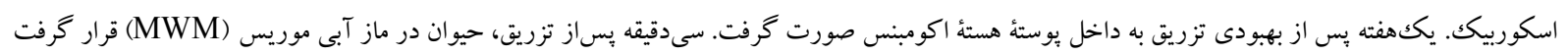 \\ و شاخص هاى ياد گيرى و حافظة فضايى ثبت و تحليل شد. نتايج نشان داد اسيداسكوربيكك به طور معنىدارى در دوز

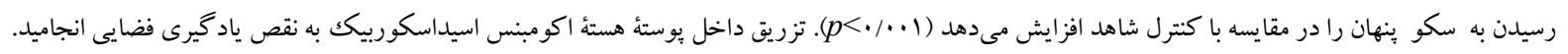 \\ وازههاى كليدى. حافظة فضايى و ياد گيرى، اسيد آسكوربيك، يوستهٔ هستة اكومبنس، ماز آبى موريس
}

\title{
The effect of intra-nucleus accumbens shell injection of ascorbic acid on spatial learning and memory in adult male rats
}

\author{
Fatemeh Shahsavari, Mehdi Abbasnejad, Reihaneh Naderi and Saied Esmaeili Mahani \\ Received 26.04.2014/ Accepted 19.05.2015
}

Department of Biology, Faculty of Science, Shahid Bahonar University, Kerman, Iran

*Correspondent author: mabbas@mail.uk.ac.ir

\begin{abstract}
Ascorbic acid (AA) as a vitamin and neuromodulator is present in most parts of CNS such as nucleus accumbens shell (Acbsh). This study evaluates the effect of intra-nucleus accumbens shell injection of AA on spatial learning and memory. 35 adult male Wistar rats (220-270 g) were divided into 5 groups: control (intact), sham AA (injected normal saline as AA vehicle) as well as 3 groups of AA (12, 24 and $48 \mu \mathrm{g} / \mathrm{rat} / \mathrm{side}$ ). After one week of recovery injections were performed. Thirty minutes after each injection the rats were trained in the Morris Water Maze (MWM) and spatial learning and memory parameters were recorded and then analyzed. The results showed that AA at the dose of $48 \mu \mathrm{g} / \mathrm{rat} / \mathrm{side}$ significantly increased the travelled distance and latency time to reach the hidden platform in comparison with either control or sham groups $(p<0.001)$. Intra-Acbsh injection of AA led to deficiency of spatial learning.
\end{abstract}

Keywords. spatial learning and memory, ascorbic acid, nucleus accumbens shell, morris water maze 
نوع ץ (D2) در مركز بيشتر است (Prinssen et al., 1994). مقدمه

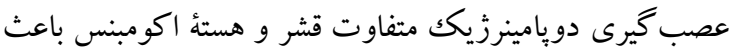

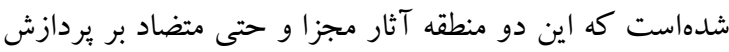
اطلاعات داشتهاشند. قشر بيشتر در كنترل رفتارهاى ترجيحى درخصوص يادگيرى با تغذيه مرتبط است، درصورتى كه مركز

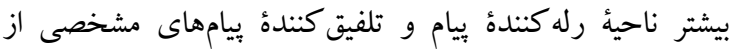
ليمبيك و قشر مغز است (Ito \& Hayen, 2011).

بهنظر مىرسد دويامين ممكن است حافظه و ياد گيرى را ازطريق تنظيم جريان از ورودى هاى مختلف ليمبيكك به هستهٔ اكومبنس دونس

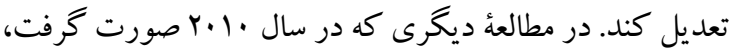
اولين شاهد را فراهم كرد كه زير نواحى يوسته و مركز هستئ اكومبنس و عصب گيرى دويامينرزيكى آنها در اشكال مختلف

حافظهشناختى در گير است (Nelson et al., 2010).

ويتامين C يا اسيدآسكوربيك (AA: Ascorbic acid)، در كروه ويتامينهاى محلول در آب قرار دارد. اسيدآسكوربيك در مغز بستانداران بيشاز هر بافت ديخرى تجمع يافته است.

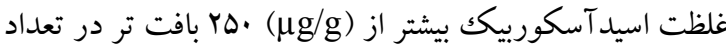

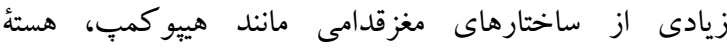
اكومبنس، جسم مخطط، هييوتالاموس و سيتوم است Liu et) (al., 2000) علاوهبر نقش آنتىاكسيدانى، اين ويتامين بهمنزلة

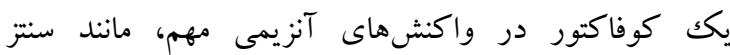
كاتكولامينها، كلسترول، آمينواسيدها، برخى هورمونهاى يتيدى و توليد نورابى نفرين از دويامين عمل مى كند Gu et)

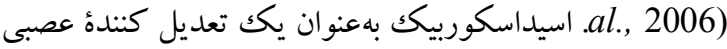
(Liu et al., در سيستم عصبى مركزى نيز معرفى شده است

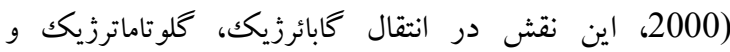
دويامينرزيك، كولينرزيك و رفتارهاى مرتبط با آنها به اثبات رسيدهاست (Gu et al., 2006). آزادسازى آن از سلولهاى

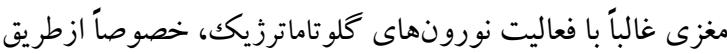
مبادله خلاف جهت آسكوربات-كلو تامات از غشاى نورونها يا سلولهاى كليال همراه است (Mogenson et al., 1980). تصور مىشود كه اسيدآسكوربيك داراى اثر خنثى كننده و متضادى بر تنظيم سيستم دويامينرزيك باشد. اثر اسيدحافظة فضايى و ياد گيرى از عالى ترين سطوح عملكردى دستگاه عصبى مركزى قلمداد مىشوند. يادگيرى بديدهاى عصبى است كه طى آن موجودات زنده ازطريق تمرين، رفتار خود را تغيير مىدهند، درحالى كه حافظه به روند ذخيرهسازى آموختها اطلاق مى شود. هستهُ اكومبنس بخشى مهم درخصوص ارتباط

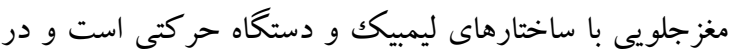
تنظيم جنبههاى گوناگون كنترل حركت، انخيزش و يادگيرى درگير است (Mogenson et al., 1980). درحالحاضر نقش هستُ اكومبنس در حافظه و يادگيرى هدف توجه بيشترى قرار كرفتهاست، اما دربارة اينكه جِكونه بخشهاى مركزى و قشرى اين هسته در اين فرايندها مشار كت مى كنند شواهد كمى موجود است (Nelson et al., 2010). كزارش شده است كه اين هسته در يادكيرى مربوط به تغذيه مشاركت مى كند (Ramírez-Lugo et al., 2006)

هسته اكومبنس آورانهاى متراكمى از ساختارهاى مغزى درگير در فرايندهاى حافظه و يادگيرى غيراجتماعى مانند تشكيلات

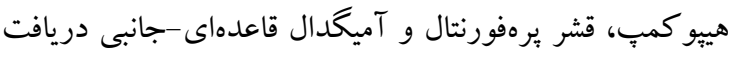

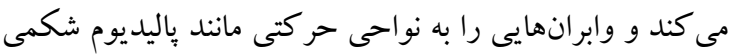

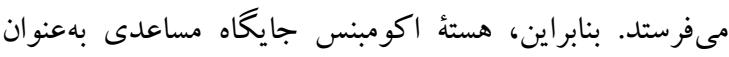

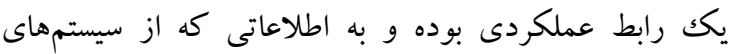

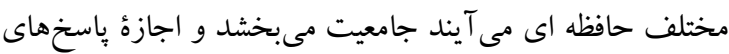
رفتارى سازشى را مىدهد (Nelson et al., 2010).

هسته اكومبنس باتوجه به عملكردش، يك ساختار ناهمخن آناتوميكى است و دست كم دو بخش متفاوت شامل يوسته و مركز در آن تشخيص داده مىشود (Miquel et al., 1999). بهنظر مىرسد يوسته و مركز بهواسطةُ مجموعههاى متفاوتى از نورونهاى دويامينرزيكى عصب كيرى شده باشند. يوسته حاوى شبكة دويامينى غنى ترى نسبت به مركز است و غلظت دويامين در بوسته بيشتر است. به نظر مىرسد باندشدن گيرندة دويامينى

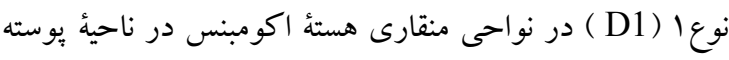

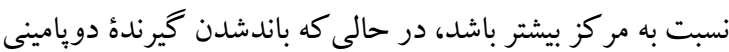


بر فرايندهاى حافظه و يادگيرى در موشهاى صحرايى به وسيلة

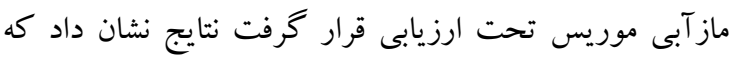
تزريق درونبطنى اسيدآسكوربيكك با دوز (mg/rat) 9 مقدار

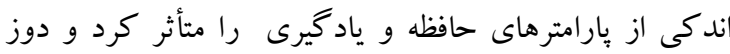

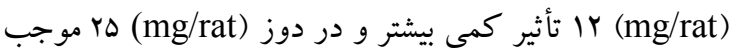

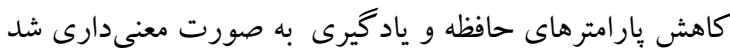

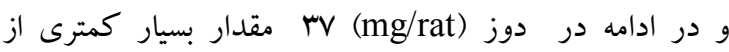

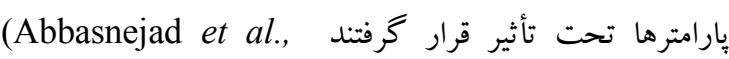

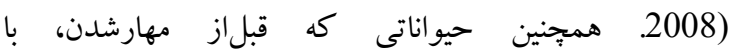

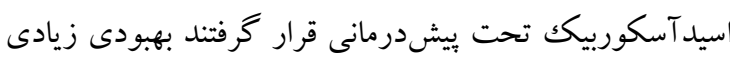
در نخهارى حافظه در آزمونهاى مشابه حافظه نشان دادند

.(Kumar et al., 2009)

Iro (mg/kg/ip) اخيراً روشن شده است كه اسيدآسكوربيك برخى اختلالات حافظه و يادگيرى را در موشهاى بير (دوازده

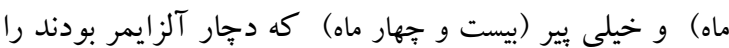

بهبود بخشيد (Harrison et al., 2009).

ازآنجاكه مطالعات قبلى مويد اثر دوجانبه اسيدآسكوربيكك بر

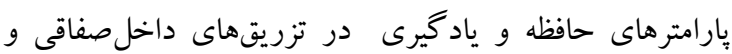
تزريق درونبطنى (ICV) است و باتوجه به نقش هستة اكو مبنس در حافظه و يادكيرى و نيز باتوجه به اثر اسيدآسكوربيكك بهعنوان تعديل كنندة عصبى در سيستم دويامينى و نيز رهايش

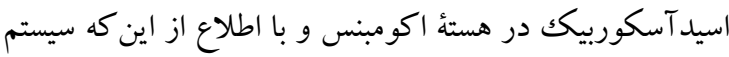
دويامينى در يوستهٔ هسته انتشار بيشترى نسبت به مركز دارد و مطالعات قبلى ما نيز در جهت مطالعهُ يوسته هسته اكومبنى بوده است، هدف تحقيق حاضر بررسى اثر تزريق اسيدآسكوربيك

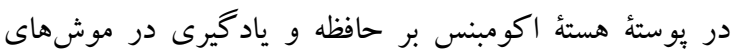
صحر ايى نر در مدل ماز آبى موريس تعيين شد.
آسكوربيك بر سيستم دويامينرزيك بسيار به ميزان دوز وابسته

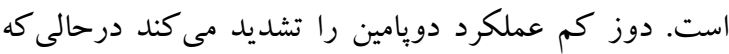
دوزهاى بيشتر از عملكرد آن جلو گيرى مى كنند .al., 2007)

بررسىها نشان دادهاست كه اين ويتامين همجِون آنتا گونيست دويامين در مغز عمل مى كند و آزادشدن دويامين درون هستئ اكومبنس را كاهش مىدهد (Ito \& Hayen, 2011). علاوهبر اين، شواهد نشان دادهاست كه اسيدآسكوربيك تغييرات رفتارى را كه آكونيست دويامين (D-amphetamine) ايجاد كرده است را را كاهش مىدهد (Sahraei et al., 2007).

اسيدآسكوربيكك مىتواند اتصال آگونيستهاى گيرندة

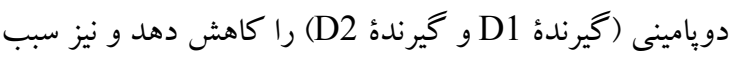
كاهش توليد آدنوزينمونوفسفات حلقوى (cAMP) در سلول

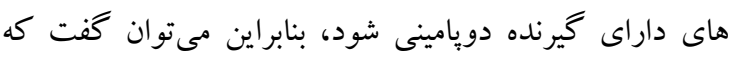
فعاليت اين دارو با مهار سيستم دويامينى همراه است Tolbert) (اسيدآسكوربيك اثر آنتى دويامينى هالويريدول همراه را در موشها افزايش و به طور مستقيم نواحى اتصال دويامينى

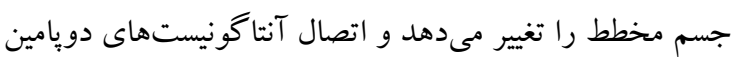
را به گيرنده هاى دويامين مهار مى كند (Liu et al., 2000).

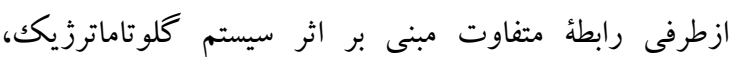

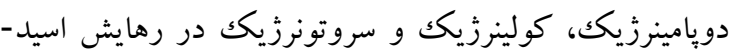
آسكوربيكك وجود دارد (Morris, 1989).

آسكوربات (11gr/kg i.p) به طور معنىدارى سطح يادگيرى

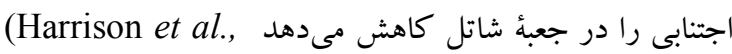

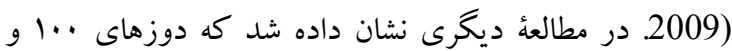

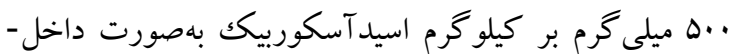

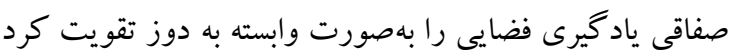

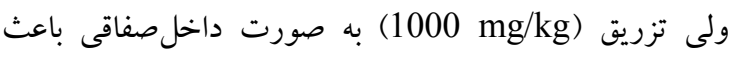

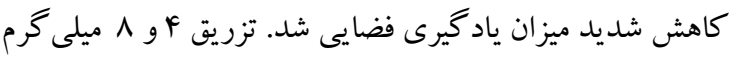

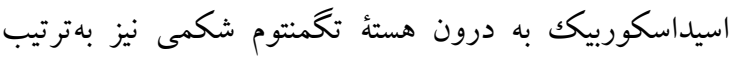

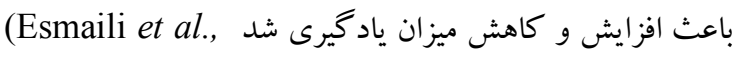

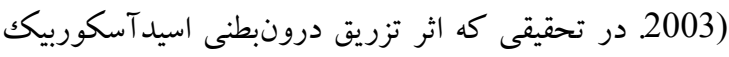


way ANOVA ازطريق نرم افزار SPSS مورد تجزيه تحليل

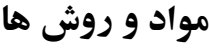

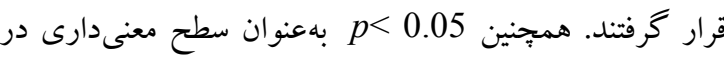

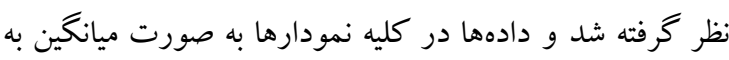

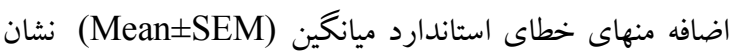

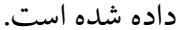

نتايج

مقايسٔ گروه كنترل و شاهد اختلاف معنىدارى را نشان نداد.

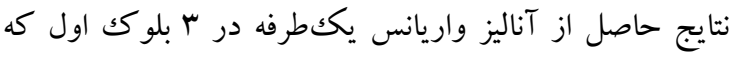

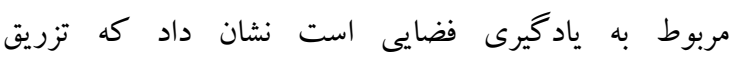

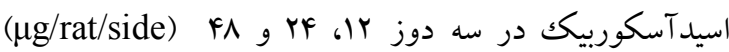
باعث افزايش ميانكين كل مسافت طى شده براى يافتن سكو دور

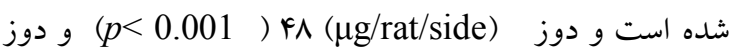

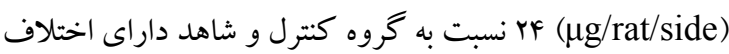

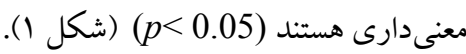

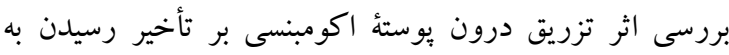

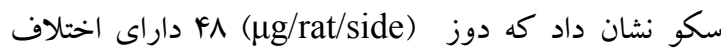
معنى

نتايج تزريق درون يوستهُ اكومبنسى بر زمان كذراندهده در ربع

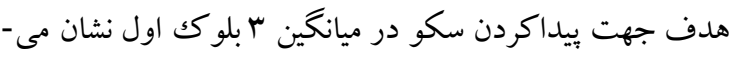

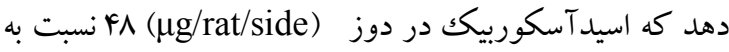

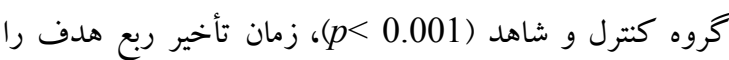

$$
\text { افزايش داده است (شكل r). }
$$

نتايج بررسى حافظة فضايى با آزمون يروب نشان داد تزريق داخل يوستهٔ اكومبنسى اسيدآسكوربيك دربارة مسافت طى بشده

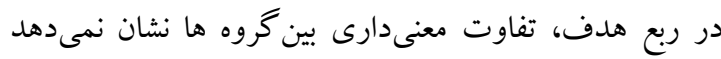

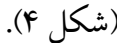

همجنين مشخص شد اسيدآسكوربيك ميانكين زمان در ربع هدف در آزمون بروب را نيز متأثر نكرده است (شكل هادئ.
در اين يُزوهش، هب سر موش صحرايى نر بالغ نزاد ويستار، در

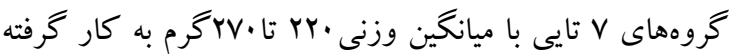
شدند. براى رسيدن به يوستهٔ هسته اكومبنس جراحى

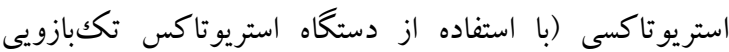
(Stoeling Co., USA اكومبنس = (5.6mm) با استفاده از اطلس ياكسينوس -واتسون روى جمجمه حيوان علامت گذارى شد (Badreh et al., 2009). بعد از طى نى دورة بهبودى (يكك هفته بعد از جراحى) تزريق داروها با حجم 1 ميكروليتر به صورت دوطرفه، ·r دقيقه قبل از آزمون رفتارى

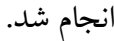

سنجش حافظه و يادگيرى با استفاده از مازآبى موريس

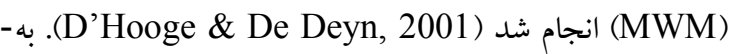
طورخلاصه اين تست شامل دو مرحله مى باشد. مرحله اول

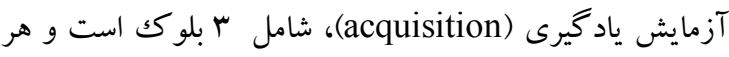
بلوكك خود شامل \& كار آزمايى است. در هر كار آزمايى حيوان

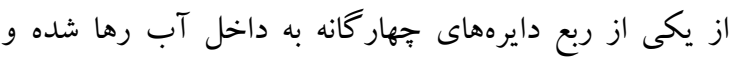

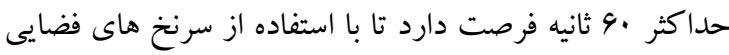

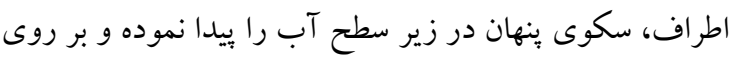

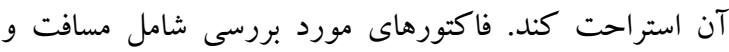

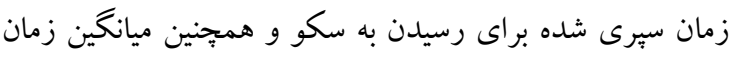

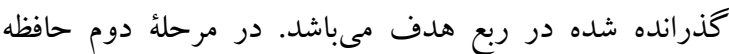

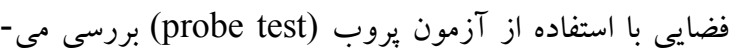

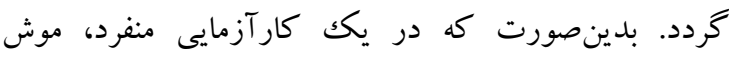

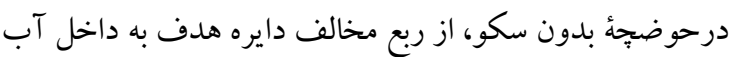

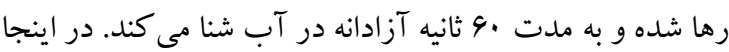
متغيرهاى مورد بررسى شامل مسافت و زمان طى شده در ربع هدف مىباشد. تصاوير با دوربين نصب شده در بالاى قسمت سترن مركزى حوضجه با سرعت ها تصوير در ثانيه ازطريق مانيتور

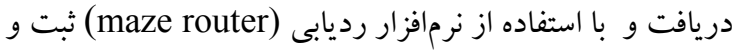

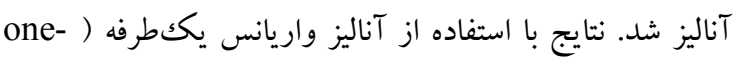




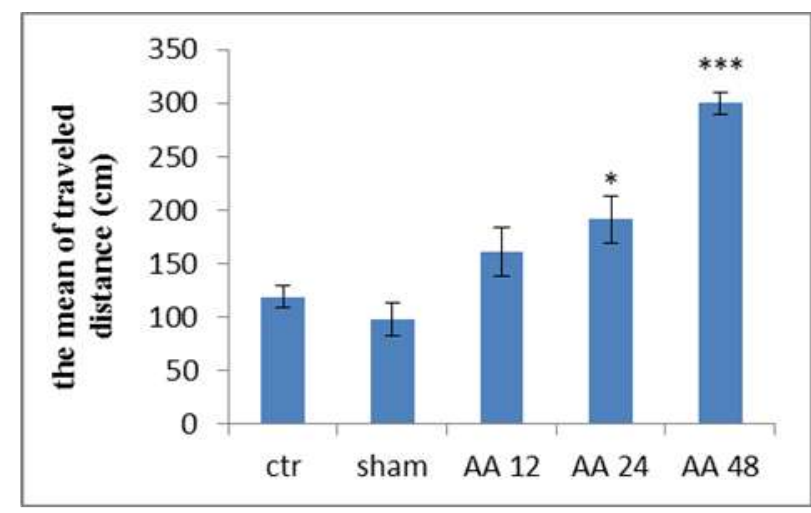

شكل 1- اثر اسيد آسكوربيكك بر ميانگين مسافت طىشده براى يافتن سكو.

Fig. 1. The effect of ascorbic acid on the mean of traveled distance to find the platform. ${ }^{* * *} p<0.001$ vs control, sham; ${ }^{*} p<0.05$ vs control, sham

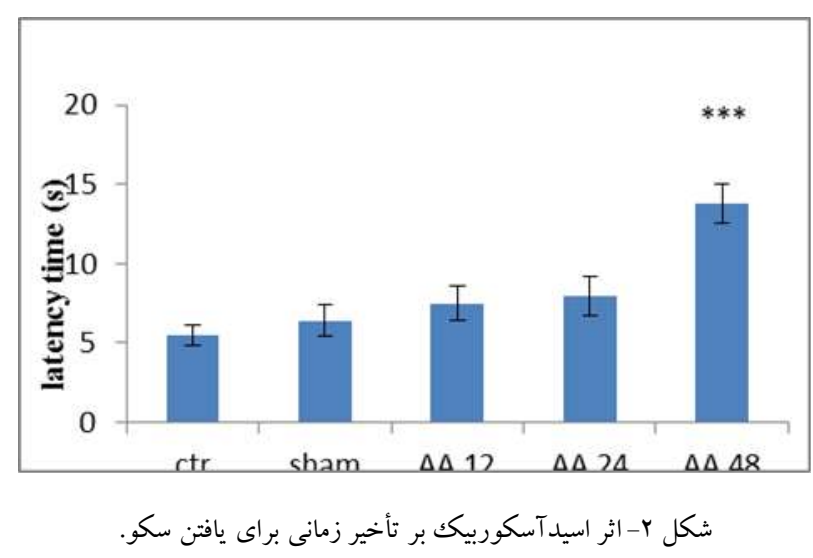

Fig. 2. The effect of ascorbic acid on the latency time to find the platform. ${ }^{* * *} p<0.001$ vs control, sham

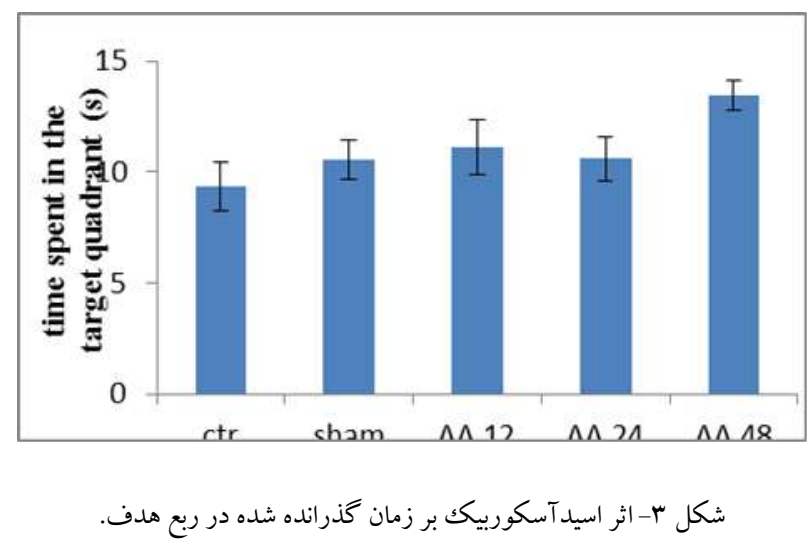

Fig. 3. The effect of ascorbic acid on the time spent in the target quadrant. 


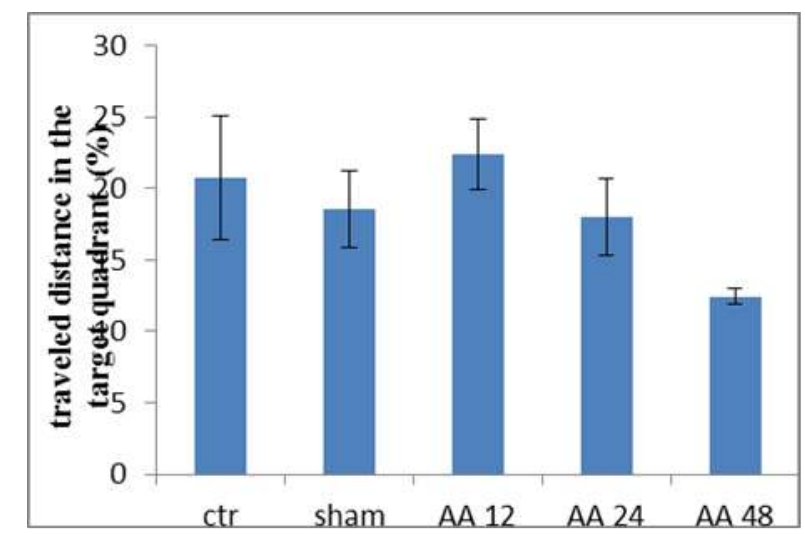

شكل F- اثر اسيد آسكوربيك بر درصد مسافت طىشده در ربع هدف در آزمون بروب.

Fig. 4. The effect of ascorbic acid on the percentage of traveled distance in the target quadrant in probe test.

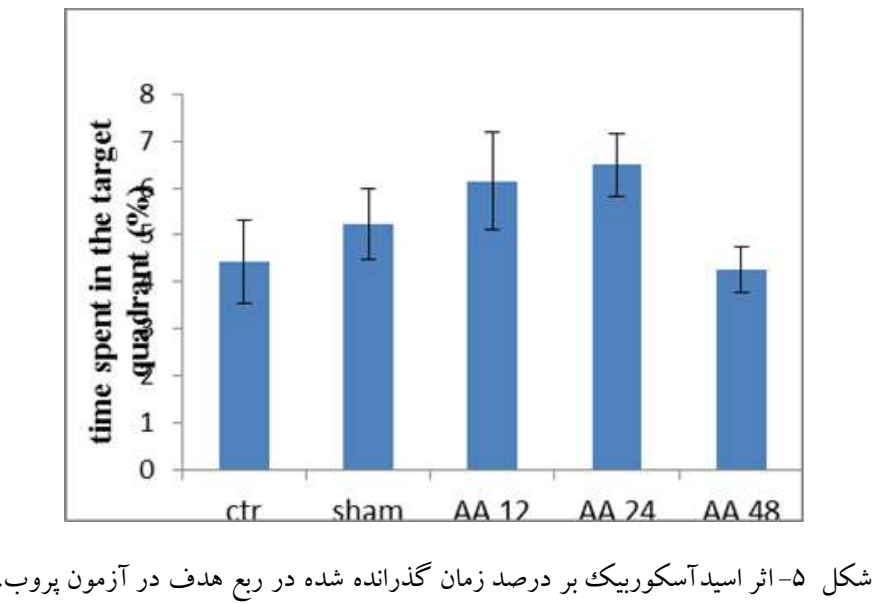

Fig. 5. The effect of ascorbic acid on the percentage of time spent in the target quadrant in probe test.

افزايش مسافت و زمان طىشده براى يافتن سكو انجاميد كه

$$
\text { كاهش ياد گيرى را نشان مىدهد. }
$$

اسيدآسكوربيكك بهمنزلهُ يكك كوفاكتور در جندين واكنش آنزيمى شامل سنتز كاتكولآمينها و توليد نورابیىنفرين از دويامين مشاركت مى كند (Gu et al., 2006). آسكوربات به عنوان يكك تعديل كنندة عصبى در انتقال ابائرزيك، كلو تاماترزيك،، دويامينرزيك، كولينرزيك و روفتارهاى مرتبط با آنها اثر دارد (Gu et al., 2006). همه انتقالدهندههاى عصبى ييش كفته به نوعى در كنترل حافظه و يادگيرى نقش دارند
در مطالعات قبلى نشانداديم كه سيستم دويامينى هسته اكومبنس (Badreh et al., متأثر از اسيدآسكوربيك مىباشد و در تغذيه

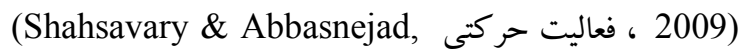
(Naderi \& Abbasnejad, 2013) 2013) موشهاى صحرايى نقش دارد. در اين مطالعه اثر تزريق داخل

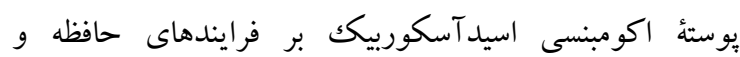
ياد گيرى در موشهاى صحرايى ازطريق ماز آبى موريس تحت بررسى قرار گرفت. نتايج نشان داد كه تزريق داخل بوسته هسته اكومبنسى اسيد آسكوربيك با دوز (F) ( 
هستُٔ اكومبنس براى تثبيت اطلاعات حافظه فضايى لازم است

.(Ferretti et al., 2005)

موضوع ديخر و شايد عمومىتر درخصوص اسيداسكوربيك،، داشتن اثر آنتىاكسيدانى است. اسيدآسكوربيك بهمنزلهُ يك آنتىاكسيدان خوب از سلولهاى عصبى محافظت مى كند و يراكسيداسيون لييدهاى غشايى رات كاهش مىدهد (Castellano et al., 2001). وجود اين اثر عمومى اسيد-

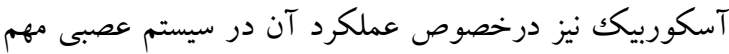

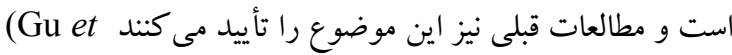

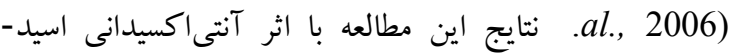
اسكوربيك بر حافظه و ياد گيرى تناقض دارد. اثر مداخلة اسيد-

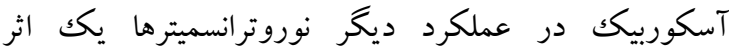
اختصاصى و اثر آنتى اكسيدانى آن يكك اثر عام است. بنابراين اثر مداخلة اسيدآسكوربيكك در عملكرد نوروترانسميترها ازجمله دويامين، گلوتامات و سروتونين از تأثير آنتىاكسيدانى آن بر ياد كيرى اثر بيشترى دارد.

براساس نتايج مطالعه حاضر تزريق اسيدآسكوربيك در يوسته

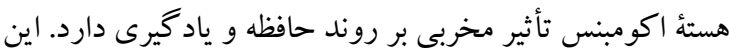

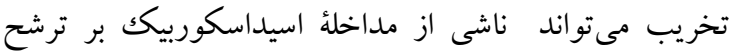

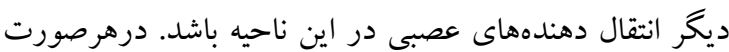
شناخت سازو كار دقيق اين فرايند به تحقيقات بيشتر در اين زمينه

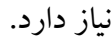

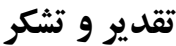

نويسند كان مقاله از معاونت يُوهشى و تحصيلات تكميلى دانشكاه شهيد باهنر كرمان به منظور بشتيبانى تشكر مى كنئد.
(Tou \& Wade, 2002)

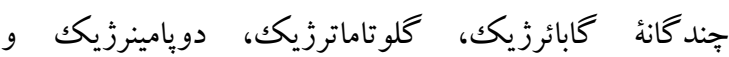
كولينرزيك در هستهٔ اكومبنس احتمال اثر تعديلى اسيد-

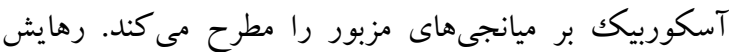

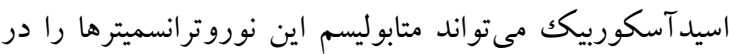
موضع رهاشده تنظيم و بدينطريق در عملكرد فيزيولوزيكك آن - ماند ها دخالت نمايد. براى مثال مشخص شده رهايش دويامين،

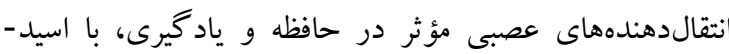
آسكوربيكك همراه است (Abbasnejad et al., 2008). هستئه

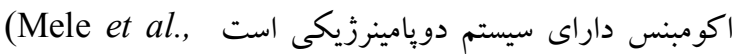
(2004 كه مطالعات بيشين نشان دادهاند اين سيستم در فعاليت حركتى و ترجيح مكانى شرطىشدن نقش دارد

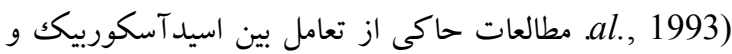

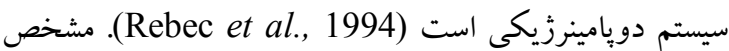

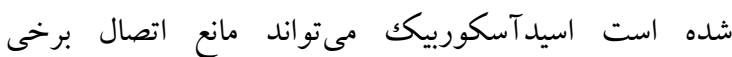
آكونيستهاى اختصاصى D1 و D2 به كيرندههاى خودشان

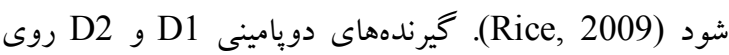
دندريت و ترمينالهاى بيشسينايسى در يوسته و مركز اكومبنس (Cools et al., 1995; Setlow, 1997; Gu et وجود دارند (al.,2006. در مطالعة ديخر گزارش شده است تجويز

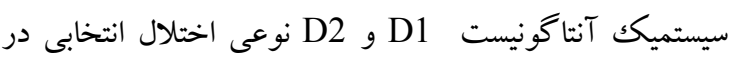
شناسايى تغيير فضايى القا مى كند (Adriani et al., 2000). بنابراين باتوجه به نقش آنتىدويامينرزيكى اسيدآسكوربيك

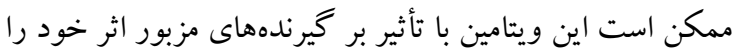

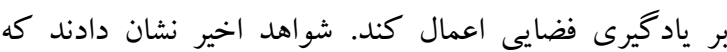
تجويز داخلاكومبنسى آنتاكونيستهاى گكلوتامات يات يا دويامين، تثبيت حافظهُ فضايى را دجار اختلال مى كند. بنابراين، بر بائ يافتهاى مولكولى و بيوشيميايى كه تعامل بين زيرمجموعههاى

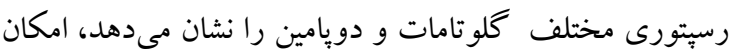
دارد تثبيت حافظه در اين ساختار ازطريق تعامل رسيتورهاى

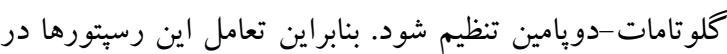




\section{References}

Abbasnejad, M., Nasri, S., Nazem, H. and Bahaaddini, M. 2008. The effect of ascorbic acid injection into the lateral ventricle on spatial learning and memory in adult male rats. Physiology and Pharmacology 12: 227-237.

Adriani, W., Sargolini, F., Coccurello, R., Oliverio, A. and Mele, A. 2000. Role of dopaminergic system in reactivity to spatial and non-spatial changes in mice. Psychopharmacology 150: 67-76.

Badreh, F., Abbasnejad, M., Derakhshani, A. and Jonaidi, H. 2009. Interaction between ascorbic acid and dopamine D2 receptor in the nucleus accumbens shell in response to feeding. Int. J. Biol. Chem. 3: 132-141.

Castellano, C., Cestari, V. and Ciamei, A. 2001. NMDA receptors and learning and memory processes. - Curr. Drug Targets 2: 273-283.

Cools, A., Miwa, Y. and Koshikawa, N. 1995. Role of dopamine D1 and D2 receptors in the nucleus accumbens in jaw movements of rats: a critical role of the shell. - Eur. J. Pharmacol. 286: 41-47.

D'Hooge R. and De Deyn P. 2001. Applications of the Morris water maze in the study of learning and memory. - Brain Research Reviews 36: 6090.

Esmaili, M.H., Doodangeh, E. and Sharif, M. 2003. The effect of ascorbic acid on spatial learning. - The Journal of Qazvin Univ. of Med. Sci. 24: 3-8.

Essman, W.D., McGonigle, P. and Lucki I. 1993. Anatomical differentiation within the nucleus accumbens of the locomotor stimulatory actions of selective dopamine agonists and damphetamine. - Psychopharmacology 112: 233241.

Ferretti, V., Florian, C., Costantini, V.J.A., Roullet, P., Rinaldi, A., Leonibus, E.D., Oliverio, A. and Mele, A. 2005. Co-activation of glutamate and dopamine receptors within the nucleus accumbens is required for spatial memory consolidation in mice. - Psychopharmacology 179: 108-16.

Gu, P.F., Wu, C.F., Yang, J.Y., Shang, Y., Hou, Y., Bi, X.L. and Dai, F. 2006. Differential effects of drug induced ascorbic acid release in the striatum and the nucleus accumbans of freely moving rats. - Neurosci. Let. 33: 79-81.

Harrison, F.E., Hosseini, A.H., Dawes, S.M., Weaver, S. and May, J.M. 2009. Ascorbic acid attenuates scopolamine-induced spatial learning deficits in the water maze. - Behavioral Brain Res. 28: 550-558.

Ito, R., and Hayen, A. 2011. Opposing roles of nucleus accumbens core and shell dopamine in the modulation of limbic information processing. $-\mathrm{J}$. Neurosci. 31: 6001-6007.

Kumar, R.S., Narayanan, N. and Nayak, S. 2009. Ascorbic acid protects against restraint stress-induced memory deficits in wistar rats. Clinics 64: 1211-1217.

Liu, W., Wu, C.F., Huang, M. and Xiao, K. 2000. Opposite effects of sulpiride and $\mathrm{SCH}$ 23390 on ethanol-induced striatal ascorbic acid release in intact and 6-hydroxydopamine lesioned rats. - Brain Res. 869: 31-38.

Mele, A., Avena, M., Roullet, P., Leonibus, E.D., Mandillo, S., Sargolini, F., Coccurello, A. and Oliverio, A. 2004. Nucleus accumbens dopamine receptors in the consolidation of spatial memory. - Behav. Pharmacol. 15: 423-431.

Miquel, M., Aguilar, M.A. and Aragon, M.G. 1999. Ascorbic acid antagonizes ethanol-induced locomotor activity in the open-field. - Pharmacol. Biochem. Behav. 62: 361-366.

Mogenson, G.J., Jones, D.L., Yim, C.Y. 1980. Frome motivation to action: functional interface between the limbic system and the motor system. - Prog. Neurobiol. 23: 69-97.

Morris, B.J. 1989. Neuronal localization of neuropeptide $\mathrm{Y}$ gene expression in rat brain. - J. Comp. Neurol. 290: 358-368.

Naderi, R. and Abbasnejad, M. 2013. Comparison of the effect of co-injection of ascorbic acid and D2 agonist (bromocriptine) with ascorbic acid in nucleus accumbens shell on male rats' anxiety. - J. Babol. Univ. Med. Sci. 15: 100108.

Nelson, A.J.D., Thur, K.E., Marsden, C.A. and Cassaday, H.J. 2010. Dissociable roles of dopamine within the core and medial shell of the nucleus accumbens in memory for objects and places. - Behavioral Neuroscienc 124: 789-799. 
Prinssen, E.P.M., Balestra, W., Bemelmans, F.F. and Cools, A.R. 1994. Evidence for a role of the shell of the nucleus accumbens in oral behavior of freely moving rats. $-\mathrm{J}$. Neurosci. 14 : 1555-1562.

Ramírez-Lugo, L., Zavala-Vega, S. and Bermúdez-Rattoni, F. 2006. NMDA and muscarinic receptors of the nucleus accumbens have differential effects on taste memory formation. - Learn. Mem. 13: 45-51.

Rebec, G.V. and Pierce, R.C. 1994. A vitamin as neuromodulator: ascorbate release into the extracellular fluid of the brain regulates dopaminergic and glutamatergic transmission. Prog. Neurobiol. 43: 537-565.

Rice, M.E. 2009. Ascorbat regulation and its neuroprotective role in the brain. - Trends Neurosci. 23: 209-216.

Sahraei, H., Aliabadi, A.A., Zarrindast, M.R., Ghoshooni, H. and Barzegari-Sorkheh, A.B.
2007. Ascorbic acid antagonizes nicotine-induced place preference and behavioral sensitization in mice. - Eur. J. Pharmacol. 56: 42-48.

Setlow, B. 1997. The nucleus accumbens and learning and memory. - J. Neurosci. Res. 49: 515521.

Shahsavary, F. and Abbasnejad, M. 2013. Effect of co-administration of ascorbic acid and bromocriptine in nucleus accumbens shell on locomotor activity in male rats by open field test. - Physiology and Pharmacology 17: 125-136.

Tolbert, L.C., Morris, P.E.J., Spollen, J.J. and Ashe, S.C. 1992. Stereo specific effects of ascorbic acid and analogues on D1 and D2 agonist binding. - Life Sci. 51: 921-930.

Tou, J.C. and Wade, C.E. 2002. Determinations affecting physical activity levels in animal models. - Exp. Biol. Med. 227: 587-600.

Shahsavari, F., Abbasnejhad, M., Naderi, R. and Saied Esmaeili Mahani, S. 2015. The effect of intra-nucleus accumbens shell injection of ascorbic acid on spatial learning and memory in adult male rats. - Nova Biologica Reperta 2: 73-81.

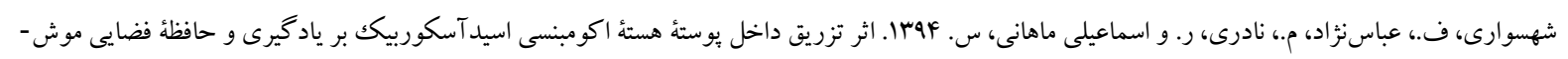

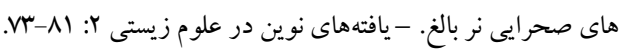


